\title{
DIRECT PETROL INJECTION versus THE CARBURETTOR FOR THE INTERNAL COMBUSTION ENGINE
}

$\mathrm{R}^{\mathrm{H}}$ EPLYING to the debate upon aircraft supply in the House of Commons, on July 10, the Minister of Aircraft Production, Lieut.-Colonel Moore-Brabazon, mentioned that where the British aero engine industry uses the carburettor, the Germans have adopted the fuel injection system. The use of direct fuel injection, as an alternative to the carburettor of spark-ignition aero-engines, is put forward in some quarters as a cure for the many shortcomings of the carburettor engine, and, in particular, as a means of improved performance at altitude. The injection may be made either before the entry to the supercharger, into the induction manifold, or directly into the engine cylinders. The German systems inject direct into the cylinders, which, having regard to the allround advantages of the three methods, is probably the best position.

The claims to superiority of the injection system as compared with the carburettor are as follows :

(1) No restriction is offered to the free 'breathing' of the engine, becaus̃e the pressure drop necessarily incurred at the venturi of the carburettor (and not recovered) is eliminated. This pressure drop is about 1 in. of mercury at ground-level and increases with altitude if the air-flow is constant, because of the fall in air density. It is only significant at altitudes above the 'rated' or full-throttle height. If the venturi is made larger, so as to reduce the 'throttling' at high altitudes, the pressure drop available for fuel metering may be inconveniently small at lower altitudes. Further, eliminating the carburettor gives a clearer entry for the air into the supercharger. The total effect, above the rated altitude, is to increase the height at which a given boost pressure, and therefore power output, is available, and hence to improve the ceiling of the aircraft. It should be noted, however, that the beneficial effect of fuel cooling, in increasing the pressure ratio of the supercharger, is lost, a factor tending to outweigh the gain conferred by reduced restriction to the airflow. The disadvantage of a low metering pressure can be eliminated by using a 'blown' or pressure carburettor after the supercharger.

(2) The induction system is freed from the hazard of 'refrigeration' icing, because the effect of evaporative fuel cooling is absent. This is a very real advantage as compared with the now obsolescent unheated carburettor, but carburettors are available which are immune from freezing trouble.

(3) There is superior fuel economy due to perfect distribution to individual cylinders. It should be noted that the air distribution is, however, unaffected. Comparative tests indicate that there is little difference in economy between the carburettor and the injection system, at least at normal air temperature. It is possible, however, that at high altitudes, when it is known that distribution becomes poor, the injection system may score. Alternatively, fuel of lower volatility may be used, although it is understood that fuel taken from German tanks indicates that no reduction in knock-rating is being made.

(4) Freedom from inertia effects. This is a definite advantage during fighting manœurring, but it applies only to the float-type carburettor. Pressure-injection carburettors are available which are equally unaffected by altitude or acceleration.

(5) Reduced risk of vapour-lock at high altitudes, due to the absence of fuel pressure drops in the system and the accompanying risk of vapour evolution. The injection pumps themselves are susceptible to vapour and air in the fuel supply and the Germans fit de-aerators to deal with this risk.

(6) The injection system would be essential for a two-stroke cycle engine in order to eliminate fuel waste during the scavenge period, unavoidable with a carburettor.

It appears that, on balance, the injection system, as compared with many present carburettors, has some slight but definite advantages. Against these must be set the extra complication of the fuel pump and nozzle, and the high standard of accuracy essential to their production and main. tenance. This latter question is not without its importance under war conditions. The Junkers system comprises 1,576 parts, 327 being different, and weighs $60 \mathrm{lb}$., as compared with the Rolls Royce Merlin's 433 parts, 141 being different, and weighing $25 \mathrm{lb}$. There is also likely to be a definite speed limitation to the injection pump, whereas no such limitation applies to the carburettor. 